\title{
Punk: Cultura e Arte
}

\section{Punk: Culture and Art}

\author{
IVONE CECÍLIA D’ÁVILA GALLO \\ Unicamp - Doutora em História Social/Pós Doutorado em Teoria Literária (IEL) \\ Professora da Pontifícia Universidade Católica - Campinas (Faculdade de História) \\ ivonegallo@superig.com.br
}

\begin{abstract}
RESUMO Este artigo analisa uma ocupação urbana promovida por um grupo de sem teto e de anarcopunks que estabeleceram moradia num edifício abandonado de valor histórico, a Estação Guanabara da ferrovia Mogiana, em Campinas (SP), nos anos de 1990-2004. O nosso enfoque é dirigido para a cultura rebelde dos anarcopunks que abordaremos através da sua produção artística; poemas, grafites e demais formas de expressão. O nosso objetivo é o de trazer para uma análise historiográfica temas e problemas convertidos em interesse mais específico das áreas de antropologia e de sociologia.
\end{abstract}

Palavras-chave ocupações urbanas, punks, cultura libertária

ABSTRACT This article deals with the squatting of a historical building, the Guanabara Train Station, in Campinas (State of São Paulo) established by a group of homeless and anarco-punks between the 1990s and 2004. My focus is mainly turned to the anarco-punks' rebellious culture mainly trough their artistic performances, poems, graffiti and other forms of expression. My

Artigo recebido em: junho/2008. 
aim is to bring in to historical analysis subjects and problems usually linked to the fields of Anthropology and Sociology.

Keywords squatt, punk, libertarian culture

Um assunto ainda pouco investigado pelos historiadores no Brasil é o dos movimentos sociais recentes. Aparentemente, não poderia haver um motivo justificado para esta lacuna se existem, no país e no exterior, grupos de referência dedicados à investigação dos problemas contemporâneos dos quais os historiadores participam em colaboração com sociólogos, antropólogos, cientistas sociais. ${ }^{1}$ Independentemente disto, encontramos uma vasta produção, no campo da sociologia, acerca dos chamados novos movimentos sociais e no campo da antropologia estudos significativos que privilegiam o espaço urbano como elemento de reflexão, considerando economia, política e cultura. Pessoalmente, penso que o historiador hoje, diante dos efeitos da modernidade, alguns dirão pós modernidade, e da globalização, munido ainda de novos referenciais teórico-metodológico, deva interrogar-se de forma diferente sobre os atributos do tempo e do passado pelos novos instrumentos de que dispõe. ${ }^{2} \mathrm{~A}$ minha opção pela investigação de aspectos do movimento punk do ponto de vista historiográfico caminha na direção de encontrar parâmetros para este tipo de abordagem, isto é, buscar as formas possíveis de interpretação do tempo pelo historiador quando lida com o presente. Mais do que isto, fazer emergir as noções do tempo que o próprio objeto de análise insinua à interpretação e, demonstrar, então, a capacidade para uma escrita da história nestes moldes, que se aproxime da sociologia, da antropologia, sem a perda de características distintivas que representem a sua particularidade no todo das ciências do homem.

Sobre estas proposições pretendo tratar neste artigo a partir da experiência de ocupação da Estação Guanabara por um grupo de anarcopunks, ocorrida na cidade de Campinas. A ocupação teve início nos anos 90 e originalmente agregava um grupo heterogêneo composto por sem teto e categorias de excluídos da sociedade, mas a minha abordagem tem como recorte cronológico o período que vai da intervenção anarcopunk neste

1 Um dos centros de referência no exterior é o Institut d'Histoire du Temps Présent, ligado ao CNRS e que desenvolve estudos sobre a história recente, isto é, pós segunda guerra, da França e de outros países. Cf. INSTITUT D'HISTOIRE DU TEMPS PRÉSENT. Ecrire l'histoire du temps présent Actes de la journée d'études de l'IHTP, Paris: CNRS, 1993.

2 Sobre isso ver HOBSBAWM, Eric. The age of extremes. A History of the word, 1914-1991, New York: Pantheon Books, 1995; do mesmo autor a interessante obra de caráter autobiográfico Tempos Interessantes. Uma vida no século XX, São Paulo: Companhia das Letras, 2002, ou ainda do autor, a recente coletânea de palestras e conferências publicada sob o título Globalização, Democracia e Terrorismo, São Paulo: Companhia das Letras, 2007. 
espaço, a partir do ano 2000, até a expulsão dos habitantes do lugar, em 2004.

Inicio este artigo com uma explicação sobre como cheguei ao tema, em seguida, com o objetivo de situar o leitor passo a uma breve história do punk para depois definir aspectos teóricos que norteiam a base da minha argumentação inspirada na arte e na cultura como fontes primárias. Finalmente, compartilho com o leitor os acontecimentos da Guanabara passados no período mencionado e, na medida do possível, interpreto e comunico, através da produção artística e cultural do grupo, a memória e a história daquelas populações.

Na verdade, a escolha do objeto, no caso que pretendo tratar aqui, não aconteceu a priori. Antes de sentir a necessidade de interpretar os punks pelos critérios estabelecidos pelo rigor acadêmico, a minha aproximação da cultura ${ }^{3}$ do grupo deu-se de modo absolutamente casual. Certa vez, ao ler os jornais pela manhã, como de hábito, soube que um grupo de anarcopunks havia ocupado o prédio da Estação Guanabara no centro de Campinas (SP). 0 assunto despertou-me 0 interesse, pois tenho dedicado a minha vida profissional ao estudo dos movimentos sociais do século XIX e início do XX, porém, não pretendia, naquele momento, escrever sobre isto ou mesmo investigar o caráter daquela ocupação. Alguns dias mais tarde, ao passar pela rua, notei num cruzamento, um punk que distribuía poesias para os passantes que assustados o repeliam e resolvi parar para uma conversa. Ele então, explicou-me que pertencia à comunidade anarcopunk que ocupava a Estação Guanabara e com a sua narrativa sensível satisfazia a minha curiosidade de pessoa comum a respeito dos sentidos do punk, da vida em comunidade, da estética do grupo. Ele também explicou, de forma um tanto apaixonada que, com a ocupação, o objetivo não era adquirir a propriedade do imóvel ou a propriedade de qualquer outra coisa, e afirmou com orgulho e determinação: "a gente não tem nada, a gente vive sem nada" de modo a me instruir sobre o espírito daquela comunidade e todo o questionamento ali levantado do conceito de necessidade, claramente

30 conceito de cultura é muito abrangente e de difícil determinação. Do ponto de vista teórico se pode abordar cultura pelo menos a partir de três considerações básicas. Inicialmente, como produção intelectual ou artística, restringindo a abordagem ao universo destes círculos. Em segundo lugar, como um modo de vida de um povo, num período ou ainda, peculiaridades de um determinado grupo, o que amplia o espectro da análise para as festas, atividades esportivas, ritos religiosos, etc. Num terceiro foco, cultura representa uma produção artística que visa significar práticas sociais e modos de vida. Estas categorias teriam sido estabelecidas por Raymond Williams no seu livro Culture and Society 1780-1950, Londres: Penguin Books/Chatto\&Windus, 1985, na tentativa de sistematizar um pensamento em torno do conceito. Da cultura não se separam aspectos diversificados de compreensão da ideologia e do poder político, de tal forma a nos alertar para usos indiscriminados dos termos. $\mathrm{Se}$, finalmente, optarmos pelo uso de cultura popular, uma nova série de questionamentos entram em jogo, dos quais trataremos mais adiante. Na historiografia o debate é bem mais amplo e procuraremos fixar alguns pontos no decorrer deste artigo, sem a pretensão de esgotar um tema tão polêmico e extenso como este, algo impossível de se concretizar em poucas páginas. VerJ ohn Storey. An Introductory Guide to Cultural Theory and Popular Culture, Athens (Georgia): The University of Geórgia Press, 1993. Na historiografia ver a produção de E. P. Thompson, Carlo Ginzburg, Natalie Zemon Davis, Peter Burke como alguns exemplos de aplicação do conceito no âmbito da história social. 
distante, como pude perceber, de uma idéia de consumo irrefletido, tão incentivada pela sociedade capitalista. Assim, quando o acaso permitia, vez por outra conversávamos naquele cruzamento e, numa dessas ocasiões eu perguntei se seria possível visitar a ocupação. Ele me disse que sim, a princípio, que apenas precisava conversar com o grupo e marcar um dia. Assim foi feito e para a Estação eu me dirigi pensando apenas numa troca de experiências o que realmente se deu até o início de 2004, quando extinto 0 agrupamento senti a necessidade de analisar essa experiência, de refletir também, sobre o meu papel enquanto historiadora a partir daqueles acontecimentos.

Inicialmente calculei a enorme dificuldade em levar uma pesquisa em condições totalmente adversas. Depois pensei: se a impossibilidade de uma análise mais profunda acerca da experiência do meu contato com os punks parecia uma realidade, em virtude do distanciamento do grupo, por outro lado, a compreensão de aspectos fundamentais sobre a história do punk em sentido mais amplo, podia ser atingida a partir da bibliografia existente sobre o tema e sobre assuntos anexos a ele, bem como a partir dos documentos produzidos pelo grupo, aos quais tive acesso, em parte, durante o período de nossa curta convivência, além, é claro, de matérias de jornais e sítios da internet que noticiaram a ocupação ou criticaram a intervenção do poder público no caso. ${ }^{4}$

Sobre o surgimento do punk parece um consenso entre diversos autores que se deu na Inglaterra na década de $70,{ }^{5}$ num momento de ascensão dos conservadores ao poder e de recessão econômica que teria provocado 0 desemprego e afetado, sobretudo, os jovens brancos pobres. As barreiras de classe, o conservadorismo, a discriminação e a falta de liberdade fomentaram a desesperança, seguida por uma atitude rebelde desses grupos que mergulhados na falta de perspectivas insurgiram-se utilizando a música como linguagem e como fator de identidade. Desse universo dos miseráveis, dos marginais, emergiu uma estética própria que aparecia à sociedade como francamente ameaçadora. De fato, a sociedade inglesa escandalizou-se com a atitude irreverente dos jovens que saíam em bandos pelas ruas em trajes estranhos, calças justas, rasgadas e remendadas por alfinetes, presas por cintos de arrebites. A esse visual assustador aliava-

4 As informações sobre o punk a seguir foram extraídas da bibliografia específica citada em notas no texto, bem como do material reunido na minha própria pesquisa de campo, jornais, filmes.

5 Aqui existe uma discussão, alguns pesquisadores ou militantes determinam a data a partir da apresentação dos Sex Pistols em Londres, em frente à loja da estilista Vivienne Westwood, outros argumentam, ao contrário, que já havia nos Estados Unidos bandas punks, entre elas o Ramones. Ver em ABRAMO, H. W. Cenas juvenis: punks e darks no espetáculo urbano de São Paulo, São Paulo: Scritta, 1994; BIVAR, A. O que é punk? São Paulo: Brasiliense, 1983; KEMP, Kênia. "Grupos de estilo jovens: o 'Rock Underground" e as práticas (contra) culturais dos grupos 'punk' e 'thrash' em São Paulo", dissertação de mestrado em Antropologia, Unicamp (Campinas-SP):IFCH, 1993, PEDROSO, Helenrose A. da Silva; SOUZA, Heder C. A. "Absurdo da realidade: o movimento punk", Cadernos do IFCH (6) Campinas(SP): Unicamp, 1983; SOUSA, Rafael Lopes de. Punk: Cultura e Protesto: as mutações ideológicas de uma comunidade juvenil subversiva, São Paulo 1983-1994, São Paulo: Ed Pulsar, 2002. 
se uma conduta crítica e transgressiva, pois ignorando completamente as determinações sociais aqueles jovens criaram um modo próprio de vida, uma cultura própria.

A palavra punk encontra significados diferentes; enquanto um substantivo pode ser traduzido como "madeira podre utilizada para acender o fogo", ou "vagabundo de pouca idade", rufião, capanga ou ainda, em inglês arcaico, prostituta. A palavra aparece também em situações muito distintas, como numa comédia shakespeareana em que o autor escreveu "Casar com um punk, meu senhor, é apressar a morte", e, numa cena do filme J uventude Transviada, de 1955, quando J ames Dean refere-se aos inimigos como punks. Punk pode ser traduzido como lixo, numa referência preconceituosa àqueles grupos como retrato da escória da sociedade. Neles se concentrava uma agressividade que a mídia logo associou à violência e à desordem. 0 fato de, nas suas origens recusarem vínculos partidários ou doutrinários facilitou a discriminação do grupo como simples baderneiros. Entretanto, a um comportamento deliberadamente desregrado, de recusa à família, à moral, ao trabalho e à cultura dominante revelavam, na verdade, um fundo de crítica contundente.

No final dos anos 70, a atitude punk foi massificada depois de ter sido desvirtuada pela mídia e isso abalou as estruturas desses grupos que viram as suas propostas serem esvaziadas do seu sentido original subversivo e entrarem no sistema das mercadorias como mais um produto disponível ao consumo. Houve um refluxo dos grupos punks e a mídia declarava a morte deles, quando nos anos 80 ressurgem no Hardcore -em sentido literal, miolo duro- como uma nova forma, mais radical e politizada que se disseminou pela Europa e EUA. Os punks passaram então, à recusa total da mídia e do mercado estabelecendo como substituto um sistema de comunicação próprio com a confecção artesanal de flyers e fanzines ${ }^{6}$ cuja circulação ficava restrita ao universo underground. Como recusa ao sistema comercial dos shows, criaram gigs ${ }^{7}$ de apresentação de bandas formadas com equipamentos rudimentares que produziam um som bruto, sem o trabalho de acabamento oferecido pelo aparato tecnológico como acontecia com as demais bandas do circuito comercial. Esse ressurgimento implicou numa aproximação com o anarquismo e, ao mesmo tempo, de uma aproximação da intelectualidade de esquerda com o que àquela altura podia ser classificado como movimento punk. Sobre a ligação de uma simples atitude punk inicial ao ideário anarquista parece difícil determinar a preferência por

6 Os flyers são folhetos contendo informações de caráter diverso sobre bandas ou sobre fanzines. Os fanzines ou zines, são revistas produzidas artesanalmente que circulam no circuito underground. Normalmente são montadas em papel A4 a partir de colagens, desenhos feitos à mão criando propositalmente uma poluição visual. A temática dos zines foi se modificando dos anos 70 até hoje, mas versa sobre música, poesia, política, sexo, entre outros assuntos.

7 Gigs corresponde a apresentação de bandas. A finalidade destas apresentações não é o lucro, mas a diversão, a troca de experiências ou mesmo a reunião de recursos em favor de coletivos necessitados de suporte material. 
alguma vertente em particular, ou por várias ao mesmo tempo, no conjunto do movimento. Sequer formamos uma idéia acabada sobre o significado do anarquismo na perspectiva punk, uma vez que, se inquiridos sobre 0 assunto, eles sempre se declaram, antes de mais nada, punks. Ao mesmo tempo, se inquiridos sobre o que é punk, afinal de contas, a resposta permanece vaga, na medida em que esta definição possa ser mais ou menos elástica de acordo com cada um. Em torno destes posicionamentos indeterminados ocorrem fragmentações dentro do todo diversificado do punk e os mais puristas rejeitam a adesão ao anarquismo apontando este vínculo como um dos fatores responsáveis pela perda da espontaneidade do punk que carregava isto como uma de suas características principais. Assim, permanece uma tensão dentro do conjunto, entre a pendência de certos segmentos para o individualismo e, para outros, pela caracterização do punk como um movimento, -o que em princípio pressupõe relações de grupo- depois da adesão ao anarquismo.

De fato, nesse momento, surgem correntes dentro do universo punk, seja de anarcopunks em suas diferentes tendências, ou os punks vegetarianos, estes últimos contestando o uso do álcool e das drogas e lançando mão de um visual menos carregado que os outros grupos. Tudo isso espelha a heterogeneidade deste movimento.

$\mathrm{Na}$ vaga do crescimento e diversificação do punk nos anos 80 , os grupos aderiram às ocupações urbanas, convertidas no período em uma prática disseminada por todos os lugares e atraía, além do mais, desde artistas e intelectuais até desempregados e sem teto, e os próprios punks. No Brasil não foi diferente. $\mathrm{Na}$ Europa, eles ocupam casas abandonadas ou prédios públicos com intuito de fundar comunidades punks. Nestas habitações alternativas estabelecem bandas, criam fanzines e montam rádios livres como mecanismos de divulgação de suas idéias. Apesar de considerarmos que a Europa garante os direitos democráticos do cidadão mais do que o Brasil, em virtude de uma margem de negociação mais ampla entre Estado e sociedade, e de políticas públicas direcionadas especificamente aos jovens, as ocupações punks de lá estão sujeitas igualmente à violência policial ou ao despejo. Infelizmente, as cenas destes confrontos raramente são divulgadas pela imprensa oficial, mas são assunto corrente da mídia independente e circulam nos sítios da internet.

Tanto a bibliografia percorrida sobre o assunto, como os sítios e produção alternativa nos informam, na verdade, sobre um universo de grupos, que se unem e se chocam no cenário urbano, entre eles os thrashs, os skinheads, os heavy metal, ${ }^{8}$ para citar os mais conhecidos. Cada grupo

8 Nas referências de Kênia Kemp, na sua dissertação "Grupos de estilo jovens: o rock underground e as práticas (contra) culturais dos grupos "punks" e "thrash" em São Paulo"; os thrashers admitem discussões sobre o nacionalismo, alguns até ligando-se a organizações racistas. Possui um imaginário voltado para o lado obscuro da 
se define a partir de uma indumentária específica e de um tipo de música. Os skinheads, por exemplo, também chamados "carecas", adotam o nacionalismo e difundem uma música que deriva do punk, denominada "oi". Surgidos na década de 60 em Londres, costumavam ouvir música negra e reggae, afastaram-se dessa proposta e ingressaram no movimento punk, mas divergindo destes aproximaram-se da extrema direita e do "White Power". Ainda é de surpreender que algumas facções do skinhead não sigam uma orientação racista, pois, ao contrário, ad otam uma militância de esquerda. De uma maneira geral identificamos os carecas pelo seu visual mais enxuto consistindo em camiseta e calça presa por suspensório, uma botina mais rústica, indumentária esta que, segundo acreditam, expressa com mais fidelidade o modelo proletário, no qual se espelham.

A compreensão sobre esses grupos de jovens se torna mais abrangente pelo conhecimento das condições históricas presentes na Inglaterra dos anos 70. Desemprego, crise das ideologias, autoritarismo, foram fatores importantes para fomentar nos jovens uma descrença com relação ao futuro e aos padrões da civilização. Inicialmente, houve a ruptura com a geração dos anos 60 e do movimento hippie, disto resultaram atitudes isoladas de rebeldia contra o sistema, mas sem uma ideologia que unificasse esses comportamentos como sendo de grupo. Com a intensificação deste processo, indivíduos com afinidades surgidas das mesmas formas de viver e pensar sentiram necessidade de criar um elemento de unidade entre as atitudes individuais de descontentamento. Uma identidade passou a ser estabelecida a partir da música e do visual, sem a pretensão, ainda, de uma anulação do indivíduo no grupo, como permanece sendo a tônica geral do movimento punk em nossos dias. Dessa proposta inicial, ou em contraposição a ela, foram surgindo novas abordagens que se chocam umas com as outras.

A questão da violência que perpassa a atitude desses grupos deve ser compreendida como mais um fator de identidade das diferentes propostas em jogo sobre como enfrentar os desafios da realidade. A atitude punk inicial de agressividade objetivava retratar o próprio universo violento no qual se dava a socialização dos jovens pobres. Hoje, quando enfrentamos, no Brasil, o problema no seu estágio o mais avançado, podemos lançar um olhar analítico mais aprofundado sobre 0 assunto. ${ }^{9} \mathrm{~A}$ violência assume deferentes formas, desde aquela de caráter estrutural, do Estado, até a disseminada pela sociedade, que vai desde a familiar, passando pela interpessoal, até

magia, da morte, do mórbido. Os skinheads são conhecidos no Brasil como "carecas", sobre eles comentaremos logo adiante e, os heavy metal ou metaleiros, são herdeiros das bandas de rock dos anos 70.

9 Cf. a produção do grupo Temático Escritas da Violência dirigido por Márcio Seligmann e Francisco Foot Hardman (IEL-Unicamp) e J aime Ginzburg (Letras-Usp). A PUC-SP também conta com um grupo de referência dedicado à questão da violência que une o Centro de Estudos de História da América Latina (CEHAL) e o Núcleo de Trabalho Ideologia e Poder, ambos nessa Universidade. 
a criminal. Essa distinção é importante, pois os alvos das ações violentas são determinados por um conjunto de fatores antecedentes e, ao mesmo tempo, definidores delas nas suas diferentes formas de manifestação. No caso do punk, a atitude agressiva inicial demonstrava uma oposição às crenças nos ideais de paz e felicidade que os hippies difund iram inspirados no orientalismo. A experiência do jovem das periferias ensinava algo bem diferente, pois cresceram no mundo da miséria, do crime, das drogas, dos abusos e da violência policial e familiar e conflitos étnicos. Munidos dos códigos dentro dos quais as suas relações com o mundo tornavam-se possíveis criaram sua cultura de resistência que consistia na recusa aos padrões vigentes. 0 enfrentamento costumeiro nas periferias das cidades foi adaptado para satisfazer às necessidades de comunicação da luta contra o capitalismo e a sociedade de consumo. A violência nesse sentido, responderá a diferentes necessidades: repelir a violência policial, repelir de uma maneira geral as relações hierárquicas e toda a forma de repressão que contribuem para gerar, afirmar a postura de rebeldia e a cultura do mundo do qual ela deriva, aceitar a violência como característica natural e necessária do ser humano que dela lança mão para reagir e para criar rompendo com o conformismo.

No momento em que os punks vieram à cena, a sociedade não estava preparada para este tipo de reflexão e a mídia contribuiu sobremaneira para a criminalização desses grupos ao difundir de forma sensacionalista os confrontos envolvendo os punks. Nos shows, por exemplo, cuspiam na platéia e dirigiam xingamentos ao público, que retribuía com atitudes equivalentes. Com isto, introduziram novas relações entre palco e platéia, desmistificando uma relação hierarquizada e mitificada entre artista e seu público. Não pretendiam ser imitados, vendidos, cultuados e massificados, como eram os ídolos do rock, então procuraram anular as diferenças entre um lado e outro desta relação ao situar as bandas como produto da atividade de pessoas comuns.

Na opinião de Graig O'Hara, o movimento punk não é um movimento violento. "Talvez 0 visual diferente, a música alta e rápida, a raiva e o sarcasmo das letras punk sejam coisas com as quais a mídia "politicamente correta" tenha dificuldade em lidar. 0 punk nunca foi um lugar para pessoas bem comportadas e de moral puritana"10

10 O'Hara é um ativista punk norte americano que publicou um livro que procurava dar conta da cena punk na América do Norte. Este material foi traduzido e publicado no Brasil em 2005 pela Radical Livros com o título de Filosofia do Punk, mais do que barulho. A fala citada de Greig O'Hara está em entrevista do repórter da Folha de São Paulo Renato Roschel publicada no caderno llustrada em 05/07/2005. Sobre os 30 anos do punk ver NEY Thiago. "Punks divergem no presente e no passado. Mostra que estréia hoje no CCBB paulista celebra os 30 anos do movimento e gera discussão sobre sua estética atual". Folha de São Paulo, SP, 5/07/2005, caderno llustrada. 
No Brasil, as tendências dos novos movimentos sociais ${ }^{11}$ que surgiram no exterior foram acompanhadas. O punk, por exemplo, já circulava na zona central da cidade de São Paulo nos anos 70, mas foi depois de 1988 que assumiu feições de movimento inclinado à esquerda do qual deriva inclusive o MAP (Movimento Anarco Punk), cujas vinculações estendem-se à COB (Confederação Operária Brasileira) e também ao CCS (Centro de Cultura Social). O MAP almeja a representação geral do punk, entretanto percebem-se inúmeras facções que resguardam as suas particularidades. Numa comparação com o punk inglês, se pode dizer que no Brasil houve uma fragmentação inicial dos punks do $A B C$, inclinado a uma atitude mais radical e fora de tendências políticas e um segundo grupo, os punks de São Paulo (da city) de onde derivou a opção pelo anarquismo. A esta divisão inicial sucederam novas.

Desde os anos 70 atuante, o punk conta com 30 anos de existência e, se inicialmente foi incluído na categoria de movimento de juventude, hoje em dia já seria arriscado enquadrá-lo neste perfil, uma vez que entre os primeiros ativistas muitos permanecem ligados, senão ao movimento, pelo menos a uma ética punk. Recentemente, uma exposição no Rio de J aneiro e em São Paulo, dava conta das comemorações em torno dos 30 anos do movimento, ${ }^{12}$ menos com 0 intuito de rememoração e mais no de afirmação de uma proposta que no seu processo permanente de transformação continua viva e ativa.

Se no refluxo do final dos anos 70 os punks fecharam-se ao contato com a sociedade, hoje, apesar de permanecerem fiéis a uma ética bastante dura e de caráter seletivo, certos grupos admitem contatos com pessoas ou grupos não-punks e, pode-se observar, vez por outra, a troca de experiências deles com o Hip Hop e até com os movimentos dos sem-teto e o MST, seguindo uma tendência atual dos movimentos sociais de estabelecimento entre si de relações horizontalizadas. A opção pela abertura ao exterior não é a tônica dominante dos punks, nem representa uma postura que parta de

11 Esta categoria foi estabelecida e aceita nas ciências humanas na tentativa de explicar e definir os movimentos sociais mais contemporâneos que apresentariam algumas características estruturais mais ou menos comuns como, por exemplo: o fato de não mais estarem centralizados na classe trabalhadora; a sua formação heterogênea, seu traço anti-hierárquico e descentralizado, instituem o cotidiano como um lugar da política, estabelecem uma cultura política até então desconhecida que privilegia a cultura de grupos e fatores de identidades entre eles, trazem novos temas e problemas para a reflexão como, ecologia, homossexualismo, interação cidade/campo, crítica à política institucionalizada. Ver, por exemplo, SADER, Emir. Quando novos personagens entram em cena. Experiências, falas e lutas dos trabalhadores da Grande São Paulo (1970-1980), Rio de J aneiro: Paz e Terra, 1988; ALVAREZ, Sonia; DAGNINO, Evelina; ESCOBAR, Arturo (orgs). Cultura e política nos movimentos sociais latino-americanos: novas leituras Belo Horizonte: Ed. UFMG, 2000. Ao mesmo tempo, novas interpretações sobre a esquerda abrem um debate como AARÃO REIS, Daniel e FERREIRA, J orge (orgs.) Revolução e Democracia (1964-...), Rio de J aneiro: Civilização Brasileira, 2007 (As Esquerdas no Brasil; 3).

12 Trata-se da mostra "Punk 30 Anos", organizada pelo colunista da Folha de São Paulo, André Fischer,que foi levada primeiro no Rio de J aneiro, depois em São Paulo no CCBB, em julho de 2005. A mostra levantou o protesto de setores do anarcopunk, pelo fato de ter sido levada numa instituição financeira, contraditando a ideologia punk, depois por apresentar o Sex Pistols como os fundadores do punk. NEY, Thiago, em matéria já citada na nota no10. 
um consenso, ao mesmo tempo em que a qualidade dessa relação, dessa abertura é relativa, sempre rodeada por desconfianças e precauções. As justificativas apontadas para o que alguns chamam de encapsulamento ${ }^{13}$ dos grupos são, em primeiro lugar, o fato de não ser consensual em um determinado meio a presença de pessoas de fora, nesse caso, seria preciso presenvar alguns membros de uma comunidade, decididos a não interagir com o exterior; em segundo lugar, um temor natural de abrir-se em virtude da repressão policial, o que restringe, portanto, o grau de confiança em estranhos à comunidade; depois, por uma questão ética acentuada pelo hardcore no que tange ao interesse comercial e ao consumo, a crítica à moral e aos costumes de tal forma que as pessoas de fora são lidas a partir dos critérios rigorosos estabelecidos pelos padrões de conduta punk. Isso, sobretudo, os torna particularmente seletivos, pois se você não é punk e reluta em ser convencido, o seu contato tem prazo de validade curto. Esse ponto, especialmente, ofereceria ocasião para uma análise mais aprofundada porque contradiz o pressuposto do respeito quase ritualizado das individualidades entre eles. De acordo com a minha observação, pude constatar em alguns momentos que a proposta sobre afinidade/não afinidade procura solucionar, mesmo que de forma não consciente, a questão das divergências internas e externas, porém isso não impede a prevalência de lideranças, sempre prontas a impor a palavra final. A proeminência de algumas figuras dentro do movimento, existe, de fato, como em qualquer outro grupo ou movimento, embora no discurso esse tipo de imposição seja negado.

Sem a pretensão revolucionária tal como é concebida pela esquerda tradicional, o movimento punk, entretanto, não deixa de ser político, mesmo nas suas facções não-anarquistas, uma vez que promove um combate diário e em pequena escala contra as teias do poder. As novas formas de se fazer política têm ganhado terreno em vários setores, sendo o movimento estudantil um dentre eles.

Novos padrões de relacionamento também têm sido cultivados como as moradias comunitárias, os coletivos e os squatts. ${ }^{14} \mathrm{Não}$ existem estatísticas seguras a respeito das ocupações. Muitas são as divergências a respeito

13 KEMP, Kênia. "Grupos de estilo jovens: o rock underground e as práticas (contra) culturais dos "punks" e "thrash" em São Paulo; p.45, refere-se ao termo que teria sido empregado tanto por CAIAFA, J anice. 0 movimento punk na cidade. Invasão de bandos Sub, Rio de J aneiro Zahar, 1986, como por GOLDTHORPE, J eff "Intoxicated Culture: Punk Symbolism and Punk Protest" in Socialist Review, vol. 22(2), Apr/jun: 35-64. 0 verbo encapsular definiria a intransigência do hardcore com o comércio e com os de fora do universo punk.

14 Squatt pode ser definido hoje como habitação comunitária de artistas e intelectuais e estudantes, que inclusive se presta para recepção de turistas na Europa. Mas a palavra também é empregada para designar uma ocupação formada por grupos heterogêneos em regime de autogestão. Na Inglaterra do século XVII, os squatters eram um segmento na categoria de homens sem senhores que ocupavam ilegalmente os terrenos comunais, as áreas incultas e as florestas e com as suas ações resistiam aos cercamentos, às determinações reais e às leis restritivas à propriedade comunal e à pobreza. Ver HILL, Christopher. 0 mundo de ponta cabeça: idéias radicais durante a revolução inglesa de 1640, São Paulo: Companhia das Letras, 1987 
inclusive de sobre quando teriam se iniciado, mas acredita-se que o fenômeno partiu da Inglaterra na década de 80 , em seguida disseminou-se pela Alemanha e Holanda, depois para o restante da Europa. Extremamente difícil parece também precisarmos a quantidade atual de edificações ocupadas e o número exato de pessoas ou grupos que nelas habitam, em virtude do rápido processo de ocupação e desalojo destas habitações.

o que importa destacarmos com relação às ocupações é que se apresentam como um fenômeno que foi se consolidando nas principais metrópoles mundiais a partir do processo de globalização e da iniciativa da burguesia em remodelar os padrões de dominação, produção e de cultura vislumbrando uniformizá-los em caráter planetário. As ocupações que consistem, em suma, na tomada de casas e prédios desocupados e/ou deteriorados, de propriedade pública ou privada, enquanto manifestações de caráter eminentemente urbano, apresentam-se como formas de ressocialização possível em substituição às formas de convivência impostas pelo capitalismo. ${ }^{15}$ Esse tipo de habitação não está centrada na família burguesa, as relações ali aceitas podem não ser monogâmicas ou exclusivamente heterossexuais, bem como as divisões das tarefas domésticas ou outras, necessárias à comunidade, não obedecem ao padrão sexual. Geralmente, localizam-se em zonas centrais, e impõem-se contra as políticas urbanas de expulsão das populações pobres para as zonas periféricas das cidades. São formadas como culturas de resistência e de reinvenção de cultura, pois encontram o seu fundamento em práticas alternativas de produzir a subsistência e, ao mesmo tempo inauguram formas plurais e incomuns de relacionamento humano. Podemos dizer que em uma ocupação economia, política, cultura não representam instâncias em separado de tal forma que a opção por uma vida neste tipo de comunidade pressupõe uma opção política. Neste caso, política distancia-se do jogo institucionalizado dos partidos para perpassar o nível das relações no ambiente privado, nas relações entre os sexos, inter classes e com a vizinhança. Um avanço com relação às ocupações dos anos 70 na Europa foi o surgimento, nos anos 80 , de Centros Sociais ocupados que promoviam várias atividades em parceria entre si e troca de informações, o que fortaleceu o movimento, sobretudo na Espanha.

Como ressaltei em outra ocasião, ${ }^{16}$ as ocupações de cunho político em termos mais genéricos não são uma novidade, tampouco na história

15 Aqui é preciso que se faça uma distinção entre as ocupações urbanas e as rurais, do tipo das promovidas pelo MST no Brasil. Com objetivos diferentes, o MST foca o aspecto primordial da sua luta na Reforma Agrária, entretanto, poderíamos também encontrar elementos de semelhanças entre estes diferentes tipos de ocupação, sobretudo na forma de gestão da economia, de caráter coletivo. Por outro lado, o MST, ou mesmo os movimentos urbanos de sem teto, não discutem a família burguesa e os grupos e padrões de sexualidade, mas numa luta política podem contar com a simpatia dos punks.

16 GALLO, Ivone. Contra-informação e cultura política. Anais do XXIV Simpósio Nacional de História, Unisinos/RS, julho 2007. 
dos ingleses, fato inclusive ressaltado no estudo de Christopher Hill, ${ }^{17}$ ao investigar a categoria dos homens sem senhores no século XVII. No mundo contemporâneo, entretanto, outras manifestações similares de aspecto contra cultural pronunciado antecederam às recentes ocupações urbanas como vimos, de tal modo que permanece uma inquietação a respeito da ruptura ou da continuidade existente entre estas várias manifestações dentro de uma perspectiva do punk que recusa qualquer filiação e adota uma atitude de contestação global. Se para o caso inglês historicamente um padrão de resistência encontra paralelos inegáveis numa irreverência punk, por outro lado, isto não quer dizer que este grupo procurasse ressuscitar os temas e os rebeldes do passado. Muito embora afirmem o discurso contra-cultural, na prática isto acontece em termos, isto é, se por um lado os punks romperam com o movimento de contra-cultura, dos hippies ao maio de 68, quando optaram pela violência no lugar do paz e amor, pelo confronto com o inimigo no lugar do simples convencimento, por outro lado, recuperaram nos seus trajes referências herdadas dos anos 50, como as calças justas e estreitas, os casacos de couro e um ar andrógino, provavelmente adaptado das performances de David Bowie. Sem contar a atual adesão ao anarquismo.

O que assistimos nas grandes cidades hoje é a irrupção de uma gama de propostas alternativas a insinuar as suas diferenças e a heterogeneidade como um dado real, mediante a produção da vida e das próprias metrópoles como cenários homogêneos. A esta pluralidade de vozes a mídia e a sociologia pós moderna atribuíram, à revelia destes grupos, a rotulação de "tribos urbanas" como uma categoria uniformizadora que buscava dar conta do problema. A escola de sociologia de Chicago teria fornecido as primeiras bases do conceito ao abordar as manifestações de jovens como delinqüência derivada da miséria do capitalismo. Os pós modernos recuperam o significado primitivo de tribo, como categoria que arranca o sentido político dos vários grupos urbanos ${ }^{18}$. Agora neles se ressalta o caráter niilista e instável para definir, de forma muito imprecisa as pequenas revoluções modernas dos nossos dias. De fato, não estamos compreendendo de forma adequada a cultura política do momento, pois ela não é hierárquica, e, no caso do punk, sobretudo, não depende de organizações ou partidos políticos, não almeja a revolução como algo distante, mas a insere numa prática de todo o dia, incorpora no viver um fazer cotidiano das crenças e necessidades que considera reais ao invés de relacioná-las num programa partidário a ser cumprido no futuro. 0 futuro não existe, o que conta é o

17 HILL, C. 0 mundo de ponta cabeça: idéias radicais durante a Revolução Inglesa de 1640, São Paulo: Companhia das Letras, 1987.

18 MAFFESOLI, Michel. o tempo das tribos: o declínio do individualismo na sociedade de massas, Rio de J aneiro: Forense Universitária, 1991. 
presente, o instantâneo que carrega o potencial das realizações tornadas fato desde já. Sobre estas realizações, não acalentam nenhuma expectativa de felicidade perfeita e eterna, como acreditavam as gerações anteriores, pois a opressão existe e dificilmente será debelada, então a solução é resistir sem trégua aos costumes burgueses, ao trabalho, reivindicar um espaço nas cidades e o acesso aos benefícios de infra-estrutura e de laser proporcionados apenas às classes médias e altas da sociedade.

\section{Cultura Popular: um debate}

Considerando que o punk se manifesta como uma cultura de protesto e de resistência e que isto é comunicado por uma ética, por uma forma particular de viver, por uma anti-arte, por uma estética da miséria, parece necessário uma definição a respeito do que seja cultura que se aplique como tradução deste universo. Acreditamos que não possa haver contradição entre, de um lado, o fato da sociedade produzir cultura e, de outro lado, o mundo acadêmico procurar explicá-las. Essa discussão é muito ampla, mas pertinente, pois se algumas linhas interpretativas desenvolvem argumentações preconceituosas acerca de grupos underground, do outro lado os punks recusam a aproximação de pesquisadores, pois "estão fartos de servirem como cobaias" para explicações que não correspondem ao julgamento que fazem de si. No fim trata-se de uma questão de compreensão da alteridade e que, de modo algum pode invalidar os esforços de interpretação dos intelectuais acerca destes grupos e de suas ações. Se existe, de fato, uma ruptura entre estes universos, e que isto impeça a total compreensão de um a outro, o mesmo não se pode afirmar acerca da relevância das produções acadêmicas na direção de uma tradução destas experiências. 0 que eu quero dizer é que, muito embora seja impossível explicar completamente algo que está deslocado da minha experiência imediata, mesmo assim ou até, por isto mesmo, contribuo para uma avaliação do outro a partir dos dados da minha própria experiência. Isto não é falsificar, é interpretar, buscar interagir. Mas, em virtude das relações de conflito na sociedade todo o resto é determinado pela fissura inicial o que torna difícil e ambígua a comunicação entre os diferentes mundos. Um punk da Estação Guanabara teria declarado "Não queremos mudar o mundo na revolução. Queremos desenvolver nosso trabalho cultural com as pessoas pobres que moram na estação. Esse lugar não é um mundo fechado. Qualquer pessoa pode vir aqui, desde que compreenda que existe uma cultura popular sendo desenvolvida às margens da cultura oficial". ${ }^{19}$

19 TONOCCHI, Mário. Estação vazia abriga "sociedade alternativa”; punks e sem-teto ocupam Estação Guanabara, em Campinas. Folha de São Paulo, SP, 05 jan, 2003. 
Dito isto, passo a um breve apontamento sobre as questões que norteiam a interpretação que proponho nos domínios da cultura.

Numa definição sociológica a palavra cultura pode ser conceituada de diferentes maneiras. Apenas para nos referirmos a duas matrizes fundamentais do pensamento contemporâneo, dizemos que a partir de Weber, por exemplo, esta discussão assumiria um caráter superestrutural, a partir de Marx, se confundiria com os modos de produção da vida material. 0 historiador social, quando descobre a cultura como um conceito imbricado ao seu ofício, envolve-se no extenso debate teórico acerca da validade ou não do conceito de cultura popular, decorrente daquelas proposições anteriores. Como podemos notar, não existe apenas uma concepção de cultura ou a mais verdadeira, mas um debate que vem sendo estabelecido historicamente, o que nos leva a imaginar o caráter dinâmico do conceito que acompanha por sua vez, a própria dinâmica das transformações sociais. Mais do que isto, a interpretação das culturas e a formulação de conceitos definidores a respeito, não estão isentas das escolhas ideológicas. No campo das nossas preferências optamos pelo debate travado no bojo da história social. Assim, a historiografia inglesa mais recente opta pelo conceito de cultura de resistência, a historiografia italiana desenvolve o conceito de circularidade, em que uma cultura popular não aparece de forma totalmente autônoma, ambas as linhas privilegiam um olhar antropológico no tratamento do conceito. Há também os que inviabilizam a utilização do conceito de cultura popular, considerando-o confuso, insuficiente para explicar realidades mais profundas ocultando o caráter de classe, ou mesmo outras distinções como sexo, idade, aspectos regionais ou nacionais. Apesar disso, seria conveniente nos lembrarmos de que o conceito de cultura popular teria surgido como alternativa a outros conceitos correntes e até mais obscuros como cultura de massa, cultura dominante e cultura do povo. Um agravante para um uso irrefletido do termo cultura popular seria a sua hierarquização relativamente a uma noção de alta cultura, esta sim merecedora de atenção. Neste caso, valoriza-se uma classe como definidora de padrões culturais satisfatórios: a elite, em detrimento da cultura popular erroneamente confundida com massificação. Nesta escala de valores a cultura popular, vista como cultura de massa, designaria algo sem profundidade, pobre de significado, algo meramente comercial, mercadológico compatível com 0 público ao qual se destina.

A nossa análise, ao contrário, privilegia uma definição social da cultura que pressupõe um modo de vida particular, apresenta-se igualmente como expressão de sentidos e valores e constitui uma experiência compartilha$\mathrm{da}^{20}$. Por meio das manifestações de cultura somos capazes de ascender

20 THOMPSON, E. P. Custums in common, London: The Merlin Press, 1991. 
à compreensão de significados e modos de vida na sociedade, tomando possível uma reconstrução da memória e da história não apenas por meio de características explicitadas nas falas, nos objetos e nas práticas, mas em conteúdos implícitos, sugeridos, velados.

\section{A história da Estação Guanabara e o squatt anarcopunk}

Em 1872, uma lei provincial deu origem à Companhia Mogyana de Estradas de Ferro e Navegação, empresa a que originalmente pertenceu a Estação Guanabara, inaugurada em 1883, como forma de desafogar 0 movimento congestionado na estação de partida que fazia entroncamento com a Companhia Paulista. Com as transformações econômicas operadas a partir dos anos 20, o sistema de transporte ferroviário sofrerá uma crise que gradativamente o levará ao declínio. Assim, em 1952, a estação Guanabara tendo perdido neste processo a importância adquirida no final do século XIX, acabou sendo encampada pelo governo do Estado de São Paulo. Em 1971, foi incorporada à FEPASA (Ferrovia Paulista SA) que, privatizada em 1998, extinguiu suas atividades. Antes disto, em 1974, a Estação Guanabara foi desativada e suas atribuições transferidas para a Estação Boa Vista, nos subúrbios de Campinas e de propriedade da antiga Companhia Paulista. Atualmente, o prédio pertence ao Governo do Estado de São Paulo que desde 1980 pretendia estabelecer no lugar o Centro Cultural Estação Guanabara, mas transferiu esta tarefa para a Universidade Estadual de Campinas e assinou com essa instituição, em 1990, um contrato de concessão do prédio por um período de 30 anos.

Atualmente, a antiga estação, bastante deteriorada, possui um valor histórico e no estado lastimável em que se encontra simboliza uma herança perversa de abandono, miséria e descaso ${ }^{21}$. A parte mais antiga do edifício data de 1883 e tem $334 \mathrm{~m}^{2}$. Em 1915, surgiu a gare inglesa, uma estrutura de ferro e vidro que ocupa $1522 \mathrm{~m}^{2}$ e que hoje está, como o restante das edificações, quase completamente deteriorada, desprovida de sua cobertura original. Em 1926, o edifício teria passado por reformas o que lhe confere 0 aspecto que hoje vemos, de inspiração art deco. Estes cacos de história hoje estão salvaguardados pelo Condepacc (Conselho de Defesa do Patrimônio Art́stico e Cultural de Campinas). Depois, também, de 10 anos de abandono a Universidade Estadual de Campinas hoje, com a expulsão dos moradores que ocupavam o lugar desde os anos noventa, resolveu tomar posse da área. Aqui encontramos uma sucessão de contradições. A arquiteta Lina Bo Bardi, dois anos antes de sua morte em 1992, havia projetado para o lugar a instalação de um Centro Cultural. Segundo informação do historia-

21 Até o envio desde artigo a estação encontrava-se em tal estado. Hoje está restaurada, sem que se notem os vestígios da ocupação dos punks e dos sem teto. É como se não fizessem parte da história da cidade e do edifício. 
dor Henrique Anunziato, membro da Associação Brasileira de Preservação Ferroviária, o projeto da arquiteta interferiria na arquitetura do século XIX com elementos modernistas, algo para ele inadmissível em se tratando de um espaço de preservação histórica que seria desfalcado inclusive, da sua parte mais antiga. Aqui aparece uma das razões que limitaram a iniciativa da Unicamp em implantar o projeto imediatamente, como pretendia. Depois, todas as obras dependiam de recursos, rapidamente disponibilizados pelas ações de então ministro da Cultura, Francisco Weffort que autorizou a universidade a lançar mão da Lei Rouanet, de incentivos fiscais, para captar os $R \$ 7,6$ milhões necessários para tal finalidade. Outro impedimento seria de ordem burocrática, pois a prefeitura de Campinas precisava desapropriar o terreno para o início das reformas. A pá de cal nas esperanças dos moradores da Estação Guanabara seria lançada pelo próprio Conselho de Defesa do Patrimônio Cultural de Campinas que aprovou a demolição de $480 \mathrm{~m}^{2}$ da área da estação que teria sido tombada pelo próprio Conselho. $\mathrm{Na}$ visão do secretário de Cultura de Campinas, na ocasião, Valter Pomar "para a administração, a implantação do espaço é importante e deve ser feita rapidamente". ${ }^{22}$ Tanto na administração do PSDB no governo do Estado, como na administração PT posterior, no Estado e na cidade de Campinas, o problema não foi solucionado.

O que era e permanece sendo de desinteresse para o poder público, tornou-se alvo das expectativas de uma população pobre que viu, ainda nos anos 90, a chance de encontrar um lugar onde morar. Em 2003, a população que fixou residência na estação correspondia a 30 famílias e, naquele ano, estimava-se em 30 o número de punks que se juntaram aos moradores fazendo do espaço uma comunidade com vida própria aonde antes havia apenas o silêncio da ruína. Os punks, na verdade, juntaram-se ao grupo original de moradores ainda no ano 2001, na data histórica do 10 de maio. A sua ocupação teve um aspecto político desde o início, quando grafaram na parede interna da estação, com um belo trabalho gráfico as palavras periferia central, destacadas em azul, preto e amarelo e em letras grandes. A explicação do significado daquelas palavras foi dada num documento do grupo, intitulado Projeto Pomba Negra (nome que deram ao squat, em substituição ao nome popular da Estação Mogiana), de autoria coletiva: "conceituamos como periferia não apenas as áreas geograficamente distantes do centro da cidade, mas também aquelas que foram marginalizadas e esquecidas pela sociedade em geral. 0 distanciamento, portanto é simbólico; sendo este o caso da Mogiana, que é localizada muito

22 Todas estas informações foram extraídas de TONOCCHI, Mário em matéria já citada na nota 19 deste artigo. Para uma compreensão mais abrangente sobre a transformação da arte em mercadoria com o aval do poder público sugiro a leitura de WU, Chin-tao. Privatização da cultura: a intervenção corporativa na arte desde os anos 1980 , São Paulo: Boitempo, 2006 e BRANT, Leonardo.Mercado cultural: panorama crítico com dados e pesquisas e guia prático para gestão e venda de projetos, São Paulo: Escrituras Editora, 2002. 
próxima do centro". Assim, a ocupação representa, em uma de suas facetas a emergência do subúrbio, com sua cultura, sua miséria, sua desgraça, no coração do espaço higiênico e enfeitado da burguesia da cidade. Novas inversões aparecem na própria escolha dos nomes, como por exemplo, o nome Pomba Negra que no projeto atribuem à significação da tristeza, do luto. Numa das paredes internas, em desenho de tamanho descomunal a pomba é retratada em preto, como uma fênix, e, abaixo da figura, em tons de vermelho e amarelo flamejantes, as palavras pomba negra, em gregas, representando o fogo que a faz ressurgir. Esta ave mitológica que no desenho mencionado carrega nas garras um coquetel molotov, pode representar uma releitura da fênix "oficial" tradicionalmente conhecida como símbolo da cidade de Campinas e um dos elementos do brasão da cidade.

O espaço físico, a casa, é uma condição essencial que permite o desenrolar de uma cultura tal como foi proposta pelos punks, embora as ações do grupo não se limitem àquele espaço, pois podemos caracterizálos como grupos nômades por razões ideológicas e estratégicas, isto é, por uma oposição ao conceito de família que é a pilastra do capitalismo, e também como forma de invisibilidade diante da repressão organizada, garantida pela incessante mobilidade dos grupos. Nos cerca de dez cômodos ocupados pelos punks na estação, foram sendo montadas uma biblioteca, uma farmácia que armazenava remédios alternativos, salas de aula e espaço de convivência. A biblioteca que contava com aproximadamente 600 títulos, começou a funcionar em 2002, a partir de doações de livros e também de um computador que fazia o controle dos empréstimos. Outro cômodo abrigava uma farmácia natural com os medicamentos feitos com ervas cultivadas no próprio lugar, na maior parte das vezes esses remédios eram administrados como chás, pomadas, na cura das doenças tanto dos punks como de pessoas da comunidade em geral. Outros cômodos ainda, serviam como salas de música, de esperanto, de alfabetização, cozinha coletiva, moradia e oficinas culturais que trabalhavam com material reciclável para a confecção de brinquedos e instrumentos musicais.

$\mathrm{Na}$ parte externa dos galpões, no lugar dos antigos trilhos, havia um parquinho com balanços, trepa-trepa, gira-gira, que foram recuperados pelos punks e onde brincavam as 50 crianças provenientes das famílias que ocupavam a Estação. A importância deste projeto para as crianças foi admitida por elas mesmas: "Gosto mais quando a gente brinca no parquinho, mas também quando eles arrumam coisas para a gente fazer os desenhos e as casinhas de papelão". ${ }^{23}$ A preocupação central dos punks era com a formação das crianças: "Através da arte de reciclar buscamos incentivar as crianças a despertar o interesse pelo reaproveitamento de

23 "Grupo monta estrutura de comunidade", Folha de São Paulo, 05/01/2003 
materiais como garrafas pet, jornais, papelão e etc., para fazerem artesanalmente os seus próprios brinquedos. Temos também uma parceria com 0 "Trilhares", grupo de contação de histórias infantis, formado por estudantes da Unicamp, que tem como proposta o incentivo à leitura de forma mais descontraída, diferente da rotina escolar". ${ }^{24}$ Estas atividades aconteciam às quintas-feiras pela manhã, das 10 às 11 hs e as crianças eram buscadas em suas casas e depois devolvidas aos seus lares pelos punks. Com eles as crianças brincavam e iam sendo alfabetizadas na língua materna, além de aprenderem o Esperanto, considerado como língua universal. ${ }^{25} \mathrm{As}$ atividades em geral também se destinavam aos adultos, como batuques, capoeira. É importante frisar o quanto este tipo de ação se distancia daquela proposta assistencialista que tem sido a tônica das políticas públicas dos governos, geralmente ancoradas numa visão paternalista, hierarquizada e uniformizante, da classe dominante sobre os pobres.

$\mathrm{Na}$ fase áurea da ocupação, havia, além da farmácia, da batucada, do esperanto, do parquinho, uma sessão de vídeos aos domingos, por volta das 6 horas da tarde, com entrada franca. Possuíam uma pequena videoteca, porém os vídeos apresentados, na maior parte eram alugados ou retirados nas Bibliotecas do IFCH ou da FE da Unicamp. Após as sessões havia discussões sobre o tema do filme, dirigida para uma reflexão crítica da realidade a partir das propostas apresentadas no vídeo. A iniciativa de levar à comunidade uma informação por via audiovisual fazia-se com grandes sacrifícios, sendo os aparelhos de TV e vídeo, emprestados e em péssimo estado o que dificultou a continuidade deste projeto tão importante para uma comunidade não leitora. Mas vivendo nos limites da sobrevivência não podiam dar-se ao luxo de acesso a equipamentos caros e, em virtude da filosofia política adotada pelos punks e de uma ética, resistiam à aceitação de recursos de instituições governamentais, ou não governamentais, e de empresas privadas, preferindo manter autonomia aceitando doações, reciclando materiais, produzindo poesia e artesanato. A cooperativa de bandas, a oficina de serigrafia, a reciclagem de lixo, o núcleo de produção de grafites e um estúdio de gravações fonográficas, compunham os elementos capazes de fornecer a sustentação do projeto.

Todo este trabalho viria a ser demolido em começos de 2004, quando depois de muitas ameaças e de invasões policiais foram finalmente desalojados para ceder espaço para o Espaço Cultural Guanabara projetado pela Unicamp.

24 "Desenvolvimento da criação" Periferia Central, Informativo dos moradores da Estação Okupada Mogiana, no 1, agosto de 2003.

25 O Esperanto foi criado por Zamenhof (1859-1918), judeu polonês, na tentativa de romper barreiras lingüísticas em todo o mundo. A língua teria sido apresentada ao público em 1887 e construída a partir de uma fusão de várias línguas, como hebraico, latim, grego e outras línguas modernas. No Brasil, a difusão do Esperanto deu-se principalmente, nas organizações operárias que a incluíam nos seus projetos de educação. 
Antes da expulsão, procuraram negociação com os vários envolvidos, pois não se opunham ao Centro Cultural, apenas não queriam sair da estação, mas não houve solução. Um panfleto que fizeram circular informava que "o que conseguimos até agora foi o descaso e a repressão policial que se fez presente no último dia 27 de setembro/03, com a detenção arbitrária de 9 (nove) pessoas da comunidade, onde fomos ameaçados de sermos despejados em 15 dias sem nenhuma garantia de outra moradias

Que Centro cultural é esse que pra se estabelecer precisa passar por cima da vida da gente? (...) O QUE É CULTURA?"26 (sic)

Sem outra opção de abrigo, pois foram deixados à sua própria sorte, acabaram ocupando os galpões abandonados da AMBEV, algumas quadras adiante da estação. Em poucas semanas foram novamente despejados e, mais uma vez, sem ter para onde ir (inclusive a Estação havia sido cercada, as janelas e portas lacradas), dirigiram-se aos galpões do fundo da estação. Depois, voltaram aos bairros periféricos de Campinas.

Naquele documento, os punks se indagavam sobre o que é cultura e sobre o que se entende como cultura. No caso em questão podemos dizer que o poder público encara o conceito pelo filtro liberal, constitucional, isto é, o edifício é propriedade pública, possui um valor histórico e pertence ao público em geral, portanto não poderia ser ocupado como residência de sem teto. Em segundo lugar, sobre o que se entende como valorização histórica parece difícil determinar e este conceito parece contraditório dentro da administração porque, se estava em mau estado de consenvação e não há dúvidas de que pelo abandono do poder público, o prédio teve 0 seu valor histórico esvaziado de sentido. Depois disso, e sem que conseguíssemos identificar em nome de qual interesse, alegou-se que o prédio precisava ser demolido até porque se convertera em abrigo para excluídos, que passam a ser excluídos também da cultura. Não se admitiu também que, nesse caso excepcional, a própria população tinha assumido, antes mesmo do poder público, a revitalização daquelas instalações promovendo eventos e outras atividades educacionais e culturais abertas à população, no mesmo lugar em que ainda hoje, inclusive, encontra-se cercado com portões e alambrados.

Por diversas vezes as populações que residiam na Estação foram chamadas de "invasores", termo que rejeitaram se referindo ao lugar como okupação, grafada com a letra k na fachada da Estação. A palavra é grafada desta maneira no movimento Okupa y Resiste, na Espanha, e talvez tenha sido importada de lá pela facilidade de comunicação hoje existente ou mesmo pelo contato direto com visitantes europeus e latino americanos

26 "Centro Cultural Unicamp: revitalização do espaço urbano ou homicídio cultural???????" panfleto sem autoria e sem data. 
ao squatt de Campinas. Sobre a questão da linguagem gostaria de fazer uso de uma citação esclarecedora extraída de Miguel Martinez López: ${ }^{27}$

O semiólogo Gonzalo Abril disse no mesmo lugar: "o gesto de utilizar o ' $K$ ' ( uma letra especialmente arbitrária porque corresponde fonéticamente com o som do ' $C$ ' e do ' $q$ ') tem um certo sentido insurgente e de resistência contra a escrita, que é também contra a lei, dado o caráter arbitrário das regras ortográficas, que lhe dão um significado de lei social. Por trás do pin lingüístico com o qual alguns grupos de esquerda transgridem os modos ortográficos há uma contestação clara: seu uso não prejudica em absoluto a comunicação, mas põe em questão a forma da lei “. (...)

A cultura punk supõe uma série de referências subversivas. Ela se manifesta em todos os momentos da socialização de um punk. Na roupa que veste, nos seus adereços, nas inscrições que grava nas ruas, nos seus poemas, informativos e na música e o próprio uso dos objetos, a forma como os produzem e os fazem circular portam significados. Segundo Tolstoi, o mundo contemporâneo erra na avaliação do que seja arte associando-a a beleza, ao prazer, ao sublime restringindo o julgamento da arte ao padrão estético burguês. Por intermédio deste tipo de avaliação duas coisas essenciais tombam no esquecimento: primeiro, as considerações sobre 0 processo de produção das obras de arte no mundo capitalista e o papel dos artistas nesta produção hierarquizada em que todo o trabalho coletivo para a conclusão de uma obra é desprestigiado, desconsiderado e aviltado. A segunda coisa é que a arte não se prestando a nenhuma daquelas atribuições anteriores "é, sim, um meio de intercâmbio humano, necessário para a vida e para o movimento em direção ao bem de cada homem e da humanidade, unindo-os em um mesmo sentimento". ${ }^{28}$ Nota-se que a opinião do escritor sobre o assunto é a de que a arte não nos faz compreender as coisas por um raciocínio lógico, coerente, mas pela capacidade que comporta de transmitir sentimentos, comunicá-los de uma pessoa à outra. A arte também não está apenas nos teatros, nas exposições, romances e monumentos, mas pode estar nos modos de se vestir, na decoração de uma casa, em piadas até, e não necessariamente uma boa arte seja bela.

Esta visão tão emancipada de Tolstoi para o seu tempo, em que apenas se começava a discutir a primazia de uma estética pautada nas belas artes, apresenta-se ainda muito atual. Com relação à estética punk, ela extrai os seus parâmetros do lixo, da escuridão, dos becos e das vielas o que absolutamente para a maioria das pessoas não alcança a representação do belo, nem do bom, nem do bem, entretanto, esta valorização dependerá sempre do enfoque de cada um. Dificilmente saímos do universo punk

27 LOPEZ, Miguel martinez. "Okupa y resiste, conflictos urbanos y movimiento contracultural" http://www.hartza. com/okupas3htm.

28 TOLSTOI, Leon. 0 que é arte? São Paulo: Ediouro, 2002 (Clássicos llustrados), p.77. 
incólumes com o culto da tristeza, o nillismo ritualizado como expressa fielmente esse poema assinado porFabinho, intitulado Cárcere: “Dentro de minha lápide/Enterrado vivo/Minha cela, meu caixão/Minhas lágrimas, as flores/O julgamento, meu velório/E minha sentença, a morte/No cemitério da vida/Onde vidas não são vidas/São pedaços de dor". A poesia punk e libertária traduz a vertigem da condição moderna em que o indivíduo é tragado pela multidão anônima das cidades, em que no jogo acelerado de construção e destruição do espaço a memória vai sendo tragada, em que o humano deixa de ser humano massacrado pelo trabalho compulsório. Neste cenário aterrorizante, em que o acaso determina a existência, a luta pela sobrevivência, a precariedade da vida que transcorrem na atmosfera cinzenta das cidades industrializadas motivam os poemas libertários como uma linguagem rebelde apta a desconstruir a calma aparente artificialmente produzida pela ordem e pelo regramento da cidade burguesa. Na fala dos punks do Pomba Negra, a "poesia é uma flor maldita que rasga o concreto...". Tomemos como exemplo esse poema de autoria de Laia: "cheiro $\mathrm{mal} / \mathrm{o}$ cheiro de minhas axilas/é acido, corrosivo/debe ser o veneno/que supura-me/por todos os poros/corrosão social/ácido moral/desestructuração total/prazer gutural/de converter/minha raiva/em arte físico/em plástica letal" (sic).

Este poema saiu no zine La Poema, ${ }^{29}$ de produção do squatt Pomba Negra. Acompanha os versos, um desenho de fundo, uma foto de mulher, modificada pela intervenção do artista que transformou a expressão original da figura de riso de prazer em um berro de dor. Este efeito foi ating ido quando o autor, ou autores, riscou os olhos da figura com uma série de traços verticais, como se tivessem sido costurados e fez também escorrer gotas de secreção do nariz que se derramam dentro da boca aberta. Ao lado da foto, há um desenho de metade de um corpo de mulher com o braço levantado de onde exala odor pútrido, como o desenho nos faz compreender. Então, entre a palavra e as imagens há uma tradução recíproca e indissociável, na medida em que as figuras transmitem a impressão da sujeira, da violência, do mau cheiro, de um corpo supliciado. Este poema traduz muito bem uma estética punk que extrai do lixo, da desesperança a sua linguagem. Tudo isto faz parte inclusive, da apresentação do visual punk que transforma o corpo

29 No zine Ramificações que saiu em dezembro de 2003 os poetas esclarecem que "La poema é um mosaico humano...Um tapete velho de retalhos que se renovam ou se destroem. Uma ferida doída que ora inflama ora fecha... Aglutinando novas idéias, concepções...Alternando diálogos, projetos de comunicação. Contra a arte burguesa e acadêmica!!! Um suspiro de ódio ao estabelecido! Aos monumentos e tradições... DESTRUIÇÃO!!! ANTI-ART no aqui e agora...Subversão viva\&ativa. Para uma interpretação da cultura anarquista ver QUEIROZ NORTE, Sergio Augusto. "Ars Anarchia-arte, vida e rebeldia", in Revista Brasileira de História, São Paulo, v. 18, no35, pp.133-164, 1998. Para uma interpretação de fontes visuais ver, BEZERRA DE MENESES, Ulpiano. "Fontes visuais, cultura visual, História visual. Balanço provisório, propostas cautelares" in Revista Brasileira de História, São Paulo: ANPUH/ Humanitas Publicações, v.23, no-45, pp.11-36, 2003. Interessantes também os novos estudos em História e Linguagem, por exemplo, BURKE, P. e POTTER, R.(orgs) História Social da Linguagem, São Paulo: Fundação Editora da UNESP, 1997 (UNESP/Cambridge). 
em arte, mas não em arte burguesa, um corpo que passa por uma plástica letal, é o corpo-lixo, resto, que se destaca na paisagem, se arrasta com sua magreza cadavérica, sua palidez, seus trajes sujos e incomuns e que nesta fantasmagoria de seres mortos/vivos incomodam quando invadem o espaço limpo da burguesia, com seus modos rudes e sarcasmos. Se o punk representa um poema vivo, nos interrogamos inclusive sobre o lugar e a forma assumidos pela poesia no mundo alternativo.

Um outro aspecto a se destacar quanto a isto, é a própria forma de produção da arte no universo underground. Um exemplo que gostaria de citar é o da Livre Associação dos Poetas Marginais, estabelecida pelos punks do Pomba Negra que publicava seus zines a partir desta concepção de produção coletiva e sem a finalidade de lucro e que circulavam nas redes de relações do grupo.

Em suma, a arte anarquista e a arte libertária são arte livre, isto é, em rompimento com a sociedade de mercado, com os padrões estéticos pré-determinados e congelados, e com a comercialização da cultura. Ela está imediatamente vinculada à vida e usufrui das mudanças permanentes operadas no presente. Um poema, por exemplo, que fala sobre as invasões freqüentes da Estação Guanabara pela polícia nos ajuda a compreender melhora relação arte/vida e rebeldia: "Dos consistentes muros de um lugar esquecido/ecoam os gritos do desespero. Em turbulentas noites de ameaça, a paranóia/se apodera do meu sentido./O temor de sentir-se desprotegid@ ante/a realidade do oprimido, me torna mais uma vítima/dese jogo de ambição, dolor/deste sistema fascista que mata/prende para conseguir seus objetivos/O cheiro da miséria a meu redor misturado com medo/me mostra que não somos nada ante sua moral assasina/somos tão insignificantes como para desaparecer/numa madrugada de bombas e tiros/mas nosso ódio a tal cobarde crueldade/não está sosinho...cuidado!!!/exponho a situação do cotidiano/a insetesa rondando nossas vidas/a violência do seus cães de guarda/tenta paralisar nossas ideas/aterorisarlas.../mas sempre estarão ativas!!!.(sic)

Este poema do zine La Poema aparece circundado por palavras soltas: morte, vidas em perigo, controle, insubmissão, fim trágico, programados para matar.

Por realizar-se independentemente do mercado, do gosto popular ou da crítica intelectualizada, só pode efetivar-se como autogestionada o que mais uma vez, garante independência de forma e conteúdo. Como esta arte desenvolve-se fora dos circuitos intelectualizados comunica seus conceitos de forma simplificada para que sejam absorvidos imediatamente pelo público. Isto, por outro lado, deriva de uma concepção de artista como homem comum que como qualquer um não precisa ser superdotado para uma expressão artística, ao contrário do que pressupõe a produção artística burguesa. A sua estrutura não é apenas rápida e assimilável, ela é rude. No 
poema intitulado Rancores, de autoria de J apão, podemos notar isto: (...) "nada absolutamente nada tem sentido.../respostas são facilmente elaboradas/difícil mesmo é encararo vazio de/toda esta existência capenga/valores, tradições, discursos, idéias.../centavos comprando arte/migalhas, misérias... o pão mofo está servido!/crave o seu punhal na face de seus/opressores!/ palavras de ordem...é preferível a/desordem?/escolha seu prato/cacos de vidro é bom/para mim.

Para finalizar, aponto algumas conclusões a respeito desta pesquisa. Em primeiro lugar, o papel do historiador diante dos fatos postos pelo seu próprio tempo e diante da resistência, cada vez maior dos movimentos sociais em disponibilizarem as suas fontes à consulta nos arquivos públicos. Nestes casos, o historiador vê-se na contingência de assumir o papel do antropólogo, com todos os limites que isto venha a apresentar. Talvez, a parte mais difícil seja estabelecer o distanciamento do objeto no momento de operar uma análise crítica, na medida em que não deixamos de nos envolver emocionalmente com as pessoas, suas experiências e expectativas. Porém, o papel do analista é este de obsenvar, juntar informações, relacionar as fontes e comunicar o resultado de sua pesquisa.

Em uma breve apreciação posso dizer que o punk avança em relação aos demais movimentos sociais contemporâneos no que diz respeito à proposta de fazer da política uma experiência de todo dia, de fazer da privacidade do ambiente doméstico o ponto de partida da política e de com isto, deslocar a política do Estado como lugar privilegiado. Como tudo, o movimento punk não é isento de críticas aliás a começar pela autocrítica que fizeram no final dos anos 70. No intuito de contribuir para uma reflexão, eu diria que o punk sofre o mesmo dilema dos grupos que se organizam de formas diferentes, mas pretendem não se contaminar por influências externas, como se isso fosse possível. Na maior parte dos casos, observase que se uma ética estrita é o que garante a manutenção de uma prática e de um discurso radicais de oposição, por outro lado, a continuidade deste afastamento compromete a própria existência do grupo, pois desprovido dos meios do diálogo, tende ao aniquilamento. Em segundo lugar, a resistência a um contato, impede que algumas ações sejam avaliadas com mais clareza, pois quando rechaçam o conhecimento, atuam mais no nível de uma auto avaliação de superfície. Um dos exemplos desse limite é a crença de que a federação supostamente garantiria a livre associação por afinidades e relações comunitárias não hierárquicas, algo que tive a chance de constatar como falso. Sempre existe um indivíduo que se destaca por alguma habilidade específica, ou por ser mais articulado, cuja opinião prevalece diante do grupo.

No Brasil, ocuparum imóvel não é a mesma coisa que fazê-lo na Europa. $\mathrm{Na}$ Espanha, por exemplo, até os anos 90, as ocupações não violentas não configuravam um delito, somente a partir de 1996, o novo Código Penal 
tornou possível a prisão de ativistas e o desalojo de várias ocupações. No Brasil, a lei defende a propriedade privada e o Estado dispõe dos meios não só da lei, mas da violência para garantir este direito. Há evidentemente, os interstícios da lei que permitem certa flexibilidade, como o usucapião. No caso da Estação Guanabara, este e outros mecanismos poderiam ter sido postos em ação se, da parte dos ocupantes a disposição em conhecer seus direitos e as formas de driblar as citações judiciais tivessem prevalecido. Quando veio o desalojo aceitaram pacificamente e como não havia instituições, partidos políticos, que lhes dessem sustentação não houve condições de mudar esse desfecho. Mas, foi uma opção política a de não negociar e, assim, quem poderia acusá-los de terem errado? 